\title{
Factors to Improve the Quality of Higher Education in the Non Government Universities in Bangladesh
}

\author{
Alrafa Akter \\ Department of Business Administration, Northern University Bangladesh, Dhaka, Bangladesh \\ Email address: \\ alrafa162@yahoo.com \\ To cite this article: \\ Alrafa Akter. Factors to Improve the Quality of Higher Education in the Non Government Universities in Bangladesh. International Journal \\ of Education, Culture and Society. Vol. 2, No. 4, 2017, pp. 132-142. doi: 10.11648/j.ijecs.20170204.15
}

Received: November 3, 2016; Accepted: January 13, 2017; Published: October 24, 2017

\begin{abstract}
A nation's development depends on an educated workforce and the same applies to a developing country like Bangladesh, which has made strides in providing quality education through establishing several non- government, mainly private universities. Such universities have increased remarkably, resulting in the education sector becoming more competitive and yet, many of these universities couldn't ensure the desired quality of education. Research and expert opinion seems to indicate that the quality of education of many of these universities is below par; many of them depend on part-time, inexperienced faculty. On the other hand, different facilities like, laboratory, library facilities etc. are not satisfactory. Many of the students were not familiar with the online education system such as courses being uploaded on the internet, attending class from home through servers, online library facilities, etc. This paper shows some of the facilities that are being provided by renowned private universities in Bangladesh and abroad. Furthermore, some differences between the facilities of public and non-government universities are highlighted. Based on the findings, some recommendations are prescribed that should be beneficial for all non-government universities in order to improve the quality of the higher education that they want to provide.
\end{abstract}

Keywords: Higher Education, Education Quality, Private Universities

\section{Introduction}

A total of 105 institutions represent the conventional higher education institution (HEI) in Bangladesh. Among them, universities represent about 75 academic bodies. These are segmented by management and financial structure, which include 34 public universities, 56 private universities, 2 international universities, 31 specialized colleges, and 2 special universities. There are specialized universities in both categories offering courses principally in technology, medicine, business and Islamic studies. There are two private universities dedicated solely to female students. The number of universities is growing mostly in and around the capital city of Dhaka.

Nowadays, ensuring quality in the higher education sector is one of the main concerns. It is now a major allegation that the quality of higher education is declining rapidly, and in some areas quite alarmingly. According to academicians, researchers, various committees (University Grants Commission- led High Powered Committee, 2003) or commissions report (UGC, PSC), newspaper report and public perception, it seems that the quality of education of the non government or private universities is deteriorating sharply. This situation needs to be rectified. Universities need to combine the technologies with the recent education system, which will in turn enhance the standard of education. However, some other research (IIEP, UNESCO, 2007) showed that some private higher educational institutions are providing quality education and their degrees are of the best international standards. In this context, this study has been initiated to explore the quality of education being provided by non government, mainly private universities.

\section{Literature Review}

While some studies have shown that private universities provide better quality education, there are some disadvantages of private universities, mainly the high cost of attendance and lack of consistent regulatory practices. Also, it remains to be determined whether or not students are actually more satisfied with the overall quality at private universities in Bangladesh or just with some aspects that are 
the contributing factors to quality. Private universities are expected to take initiatives to provide a higher quality education by implementing best practices in pedagogy, curriculum, instructional methods and necessary resources. With the higher cost of tuition, private universities have an economic advantage that enables them to use state of the art technology, curriculum and faculty in efforts to maintain higher quality. The challenges faced by private universities include motivation for profit, inability to attract talented students who lack sufficient financial resources, and reliance on revenue from students that force the institutions to view students as "customers" who are paying for services. Although it cannot be conclusively determined from this limited study whether the private universities or public universities in Bangladesh are of higher quality, the current study will be able to at least shed some light on the issues and provide directions toward initiatives to improve their quality.

In a study titled 'Determinants of education quality: what makes students' perception different?'Akareem and Hossain [1] surveyed 432 students from five top private universities of Bangladesh to evaluate their perception toward dimensions of higher education. The study found that status of students for scholarship, extracurricular activities, parents' education, age, previous result, and university they study in have a significant influence on perception about quality of higher education.

Accordingly, Syed Saad Andaleeb [2] in his study focused nine critical factors to revitalize quality of higher education. These factors are; teacher quality, method and content, peer quality, direct facilities, indirect facilities, administrative efficacy, political climate, gender effects and expected satisfaction with higher education. In his research, he revealed these areas seem to need greatest attention. In every area he pointed out some indicators or issues to explore the reality.

According to Bhuiyan and Hakim [3] 'The improvement of higher education facilities may attract foreign students to our country as well as local outgoing students which could generate more government revenues'.

Mohammed Ehsan [4] in his book "Higher Education Governance in Bangladesh" pointed out that qualified full time faculty members must be recruited in the private universities; at least 80 percent faculty members should be full time. Mr. Ehsan expressed his concern that, unless campus facilities are upgraded largely, we cannot expect vibrant academic atmosphere in the private universities. In his book he tried to explore the status of governance in Public and Private Universities in Bangladesh.

Mamun et al. [5] conducted a study on the students of private universities where students identified 45 variables with which their satisfaction is related. The variables are: scheduled semesters, standard class size, accessible location, drinking water on each floor, proper security, good faculty members, quick feedback from instructors, teachers' accessibility and availability, course counseling, wellequipped class rooms, up-to-date curriculum, high speed internet, teachers' evaluation, being the best business schools, library with latest edition of books and journal, career counseling, equipped auditorium, students welfare body, quality canteen, medical support, foreign faculty members, residential facilities, on-campus sports facility, students loan, emergency fire drills, transportation, cocurricular activities, flexibility in course choice, hygienic washrooms, cost-effective education, tutorial, own campus, credit transfer facility, availability of dual majors, competitions, students lounge, corporate presentation, student counseling, study tours, smoke-free campus, on-campus parking, internship facilities during study, international affiliation, and placement services after graduation.

According to Sarkar, Rana and Zitu [6] the main challenges of quality higher education in public universities of Bangladesh are teaching aids, library facilities, availability of books and journals, research facilities, and laboratory facilities. They also focus on budgetary provision and utilization

To Rony and Rashid [7] there is great controversy about the quality of education that private universities provide. Most of the private universities are running their academic activities in rented buildings without enough research facilities. The quality of education depends on quality classroom teaching.

The study titled 'Quality of Education in Bangladesh: A Survey on Private Business Schools' Hoque et al. [8] showed that faculty credentials, intake (student) selection system, assessment system, campus facilities, research environment, leadership of university, market orientation, and corporate attachment are associated with quality of business education.

\section{Research Methodology}

\subsection{Sampling Design}

The sample for this study was five private universities located at both Dhaka and Savar. A purposive sampling technique was used to select the five private universities, and then questionnaires were distributed among 50 faculty members. Ten faculty members were selected equally from each of the universities with the help of random sampling technique.

\subsection{Variables}

The dependent variable in this study was 'quality of education in non-government universities' and there were thirteen (13) independent variables. Those variables were chosen based on the above literature review in addition to brainstorming sessions with the faculty members of private universities.

\subsection{Data Collection}

The study was conducted based on both primary and secondary data. Primary data was collected through interviews and questionnaires. Structured questionnaires containing both open and closed ended questions were used. The secondary data was gathered from journals, books, 
magazines, newspapers and research articles.

\subsection{Survey Instrument}

The research has been conducted by using SPSS software specifically frequency from descriptive statistic and for the numerical calculation of the behavioral answers of all the questionnaires, The following score for all the questions has been set-

Table 1. Score of Alternative Options used.

\begin{tabular}{ll}
\hline Option & Score \\
\hline Strongly Agree & 1 \\
Agree & 2 \\
Neither agree or disagree & 3 \\
Disagree & 4 \\
Strongly Disagree & 5 \\
\hline
\end{tabular}

\section{General Discussion: Non Government Higher Education in Bangladesh}

\subsection{Non Government Universities in Bangladesh}

Non government universities, mainly private universities, are those higher education institutions which had been established privately by a group of people or an organization with the Government's permission, with an aim to expanding the opportunities for higher education among larger number of students under Private University Act, 1992 (Amended 1998) that was passed on 9th August in 1992. According to the Act, 'Private University' means; any private university established under this Act; and following the provisions of this act and in fulfillment of the conditions provided by the government, any institution managed under the affiliation of any foreign university which is operating courses of Honours or Masters Degree, Diploma or Certificate Courses or any institution which is offering Degree, Diploma or Certificates (Section-2, Sub-section-(g), Private University Act, 1992,
Amended 1998)

At present, there are 105 institutions in Bangladesh, of which 56 are private and 34 are public universities. With the expansion of education facilities in secondary and higher secondary level, the demand for higher education has increased dramatically in recent years. As the public higher institutions are not sufficient compared to the number of students, they could not successfully meet this demand and so the private sector in higher education has been increasing rapidly to mitigate this demand. As a result, the number of students in the private universities is increasing day by day. Because of the competitive environment in the higher education sector, private universities are trying to develop their education quality to sustain and make the education system digitalized.

\subsection{Growth of Non-government Universities, 1992-2013}

Through the passing of the Private University Act-1992 in National Parliament, private universities started their journey in Bangladesh. To meet the rising demand for higher education, non government universities have been established along with public universities.

North South University (NSU) was the first private university in Bangladesh and was established on 5 November 1992. The then political government of Bangladesh Nationalist Party (1991-1996) had a more favorable stance towards the private university sub sector. This is shown in the following figure.

During that period, 16 private universities have come on stream. Non government universities have not grown much during the following period (1996-2001). It is reflected in the empirical data. After this period, up to 2003 the numbers of private universities have gone up to 52 . There has been an addition of 30 private universities during this period. i.e. on an average nine to ten private universities were added each year. After 2003 and until 2013, four private universities have been established.

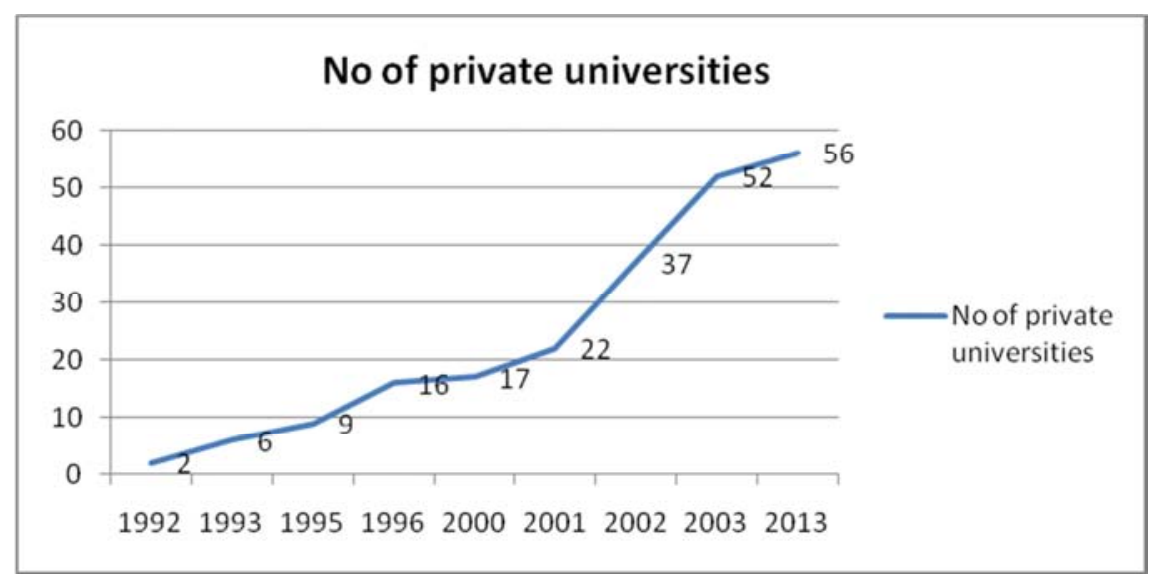

Figure 1. Growth of non government universities, 1992-2013.

\subsection{Quality of Non-Government Universities in Bangladesh}

During the early 1990s, non government universities in
Bangladesh started their operation. In spite of its faster growth, some recent studies show that these universities are performing below the expected average standards. Although very few of them are little above average, all of them have 
immense scopes for improvement.

The tuition fees of public universities is less compared to non government universities and so a large number of students wish to be enrolled into public universities, where student population of non government universities was limited. But situation is now changing. The number of students in non government universities is increasing rapidly. Relatively better quality students are getting admitted into public universities because of its competitive nature so the quality of students is often inferior in the case of non government universities. Now is the time to improve these less qualified students by providing them with better quality education.

Most of the non government universities do not integrate modern technologies with the education system such as uploading information from online in the classroom through an individual's own laptop. Latest technologies should be integrated with the education system. Again, they do not have sufficient fulltime faculty resources. Therefore, have to depend on part-time faculty. There is a shortage of qualified faculty members in some of the non government universities. Some of the non government universities have the qualified teachers but due to insufficient benefits like poor paypackage, their turnover rate is high. Due to these reasons, universities fail to draw teachers with immense potential even though they are taking higher tuition fees from the students. Furthermore, the infrastructure facilities are not sufficient and are not available in recent non government education system.

\section{Facilities Provided by Non Government Universities in Bangladesh and Abroad}

\subsection{Facilities Provided by Some Renowned Non-government Universities in Bangladesh}

\section{North South University (NSU)}

1) NSU has well trained, experienced faculty with world renowned degrees from reputable universities who help bridge the gap between text book knowledge and real life corporate world.

2) NSU has a large, spacious campus with high end facilities. It maintains a cyber and audio-visual center with Wi-Fi and broadband Internet connection.

3) It provides online library facilities. All students, faculty members and staff members of the university can browse, download and print materials from computers of the library. The audio visual unit is also equipped with TV, VCD, VCR, DVD, multi-media projector and other audio-visual equipment.

4) The library arranges orientation program every semester for the new students to demonstrate how to use the university library systems and services effectively. The library also offers a 14-week training program titled 'Certificate Course in Digital \& Online Librarianship' for those who are interested to know h3ow to use the
Internet resources in higher education and research, and how to design and maintain website, and set up online digital libraries. The faculty members and students of NSU may also enroll in this training course.

\section{East West University}

1) Internet and Computing Facilities: EWU has established 7 (seven) computer labs equipped with more than 260 computers and printers of various ranges. The operating support systems are Windows, Linux, Solaries, etc. The programming languages and package support include $\mathrm{C} / \mathrm{C}++$, Java, Fortran, Oracle, MatLab, Visual BASIC, SPSS, MS-SQL Server, MySQL, PHP,. NET etc through Information \& Communications Services (ICS) section. ICS works directly under the office of the ViceChancellor to facilitate computer lab facilities to students and to maintain computer hardware, software, multimedia systems, networking systems, and the email service of the University.

2) East West University has internet facility of $18 \mathrm{Mbps}$ band width. ICS maintains the service for smooth continuation of internal connectivity. It also provides in-house training to employees of the university to improve their computing skills.

3) Students' Welfare Department: East West University has a Students' Welfare Department to develop student experience through extra-curricular programs. There are 18 clubs under this department which give various opportunities for students to discover their hidden potential. Among them EWU Agro Industrialization Club, EWU Alfa-Beta Statistics Club, EWU Creative marketing Club, EWU English Conversation Club, EWU Science Club are worth mentioning.

4) Virtual Campus: all courses offered in the different departments are internet based in EWU. An online course page allows the student access to vital information about courses including the course information, exam deadlines, lecture plan, lectures notes, model questions, link to relevant web sites, etc.

\section{BRAC University}

1) The faculty is highly experienced in teaching; they go beyond the courses to help out a student and take into account everyone's problems and perspectives when making decisions and are very friendly and helpful. They create a strong tutor-student relationship which really helps the students with their studies.

2) BRAC BBS really helps students engage in extracurricular activities which go far beyond their curriculum. The one month TARC program, where 200 to 250 students live together in Savar, help them to build their personalities for the corporate world. The experience fosters team work, creativity and integrity.

3) This university provides verities of facilities like video conferencing courses, dialog, meeting Video Conferencing facilities for hire computer based online training, workshops, meetings, interviews and consultations teleconferences. 


\subsection{Facilities Provided by Foreign Private Universities}

\section{International University of Japan (IUJ)}

1) Students and Learning Environment: IUJ's campus is multinational. This way, students are able to learn how to work with people with different cultural, historical and social backgrounds in ways that are not easily possible anywhere else. In this campus, overseas students live together on campus and study with Japanese students who can introduce them to various sides of Japanese society and culture.

2) Practical Research Activities: IUJ provides practical research activities for all students through its close relationship with International Organizations such as the World Bank, multinational companies and regional bodies.

\section{Liberty University}

1) Online education: Liberty University is now the largest, nonprofit online private university that offers a unique approach to online education. Classes of this university are conducted in a flexible virtual classroom. Students can access their learning resources and can complete their distance learning degrees on their own schedule.

\section{Boston University}

1) Classroom Audio/Visual Equipment Reservations: Boston University provides equipment and expertise with audio/video and multimedia equipment for classes and presentations. From setup to operation, professional technicians help to enhance presentations and classroom teaching. They provide equipment such as computer projectors and slide projectors for screened presentations, television monitors with VHS and DVD capabilities for classroom screenings, and microphones for clearer and more audible lectures to enhance students' classroom multimedia experience with state-of-the-art equipment.

2) E-Portfolio Sites: E-Portfolio sites is introduced where collection of selected work in university's programs and courses are uploaded to make learning visible. It helps to publish samples of best research, projects, and school work. With no knowledge of HTML, you can create a professional online portfolio or interactive resume that will impress the academic community and future employers.

3) Course Evaluation Scanning: Course evaluation scanning services are available that provide timely and accurate results suitable for analysis and reporting. These reports are generally available two to three weeks after receiving the evaluation package. This evaluations help to make adjustments and improvements in accordance with collected student feedback. Standard forms provide a cost-effective means of capturing vital, accurate information, while custom forms can be developed to meet your specific data-capture needs.

4) Learning Management Systems: University has introduced a web-based system for managing course materials where Instructors can make announcements, share course materials, and enhance discussion, all in one easily accessible location.

5) Blackboard Learn: Blackboard Learn is the newest learning management system at Boston University which is used in on- and off-campus courses, certificate programs, and clerkships. Students can access course materials at any time and from any computer with an Internet connection. Instructors manage all course materials online, where they are immediately available to students. Instructors can post documents, make announcements, send e-mail, create online assessments, and more. Students can access course documents, send files to their instructor, and access grades directly. Course materials are available 24/7, from any location, allowing students to learn when and where they like.

\section{York University}

1) Digital Media program: York University offers digital media programs that combines science, technology, and communications with the visual, performing, and media arts. Through this, lectures will be supported by presentation software, which the faculty members will be able to control through voice commands. Discussions occur around tables, although participants can use devices mounted on walls or passed around by hand. Outside of class, students learn from rich multimedia content-3D gaming and interacting with holographic "films" using hand gestures-but do so according to a syllabus, on which they are tested.

2) Library facilities: There is a robust and extensive bilingual collection of books, print periodicals, thesis, archival material, maps, films and music CDs in York University's library. They have more than 2.6 million printed volumes, 600,000 e-books and 72,000 full-text electronic journals.

\section{Imagining the Future of Higher Education}

If we can imagine the future of higher education, we will have to consider how our campus experience will differ from that of the next generation and what changes will digital technology make.

- Internet has made our life more comfortable. It mediates most human connections. Students will be able to meet other students from far distance for group discussion, project making and so on via the internet.

- Most learning will be online based. Students will find instructors and support staff through websites of their institutions. Classes will be scheduled through negotiations between instructor and student leading to multiple, overlapping timelines. Content will be entirely web-based. Student-instructor and student-student interaction will generally be conducted online through $3 \mathrm{D}$ videos.

- There will be few campuses that will maintain a physical library. Rather, it will be fully online based so 
that students and faculty can get the book from their own homes or offices. Thus, the necessity for a huge budget for the physical library will be reduced.

- Face-to-face meetings will still take place, but not frequently. They will be reserved for instances where physical co-presence will add significantly towards learning, such as lab work, meeting with an expert offline, or deepening peer connections.
- Political unrest is a common phenomenon in Bangladesh. So home schooling will be widespread. Students will be able to attend the classes from home through a server which will be connected to the teacher's home in case of need such as general strikes, blockades, etc.

- Each and every student will need to keep one laptop in classroom as class dairy so that they can access the information anytime from anywhere.

\section{Results}

\subsection{Quantitative Findings}

Table 2. Experienced faculty.

\begin{tabular}{llllll}
\hline & & Frequency & Percent & Valid Percent & Cumulative Percent \\
\hline \multirow{4}{*}{ Valid } & Disagree & 20 & 36.4 & 40.0 & 40.0 \\
& Neutral & 10 & 18.2 & 20.0 & 60.0 \\
& Agree & 20 & 36.4 & 40.0 & 100.0 \\
Missing & Total & 50 & 90.9 & 100.0 & \\
Total & System & 5 & 9.1 & & \\
\hline
\end{tabular}

Source: Own survey, 2015

Based on the frequency tables it can be seen that, $40 \%$ of the respondents agree and equal number of respondents disagree with the statement regarding experienced faculty recruitment for improving quality of education. Although sometimes nongovernment universities have to compromise with the quality of teachers, but it is not the fundamental factor in case of improving the quality of education.

Table 3. High speed net.

\begin{tabular}{lllll}
\hline & & Frequency & Percent & Valid Percent \\
\hline Valid & strongly agree & 50 & 90.9 & 100.0 \\
Missing & System & 5 & 9.1 & 100.0 \\
Total & & 55 & 100.0 & \\
\hline
\end{tabular}

Source: Own survey, 2015

Again, $100 \%$ of the respondents agree with using high speed internet which is not fruitfully implemented in all nongovernment universities. So non-government universities should use high speed internet.

Table 4. Research support.

\begin{tabular}{llllll}
\hline & & Frequency & Percent & Valid Percent \\
\hline & Disagree & 6 & 10.9 & 12.0 & 16.0 \\
Valid & Neutral & 8 & 14.5 & 72.0 & 12.0 \\
& Agree & 36 & 65.5 & 100.0 & \\
Missing & Total & 50 & 50.9 & & \\
Total & System & 55 & 100.0 & \\
\hline
\end{tabular}

Source: Own survey, 2015

Factor research support explains majority of the respondents $(72 \%)$ agree that faculties should get sufficient support to publish quality research paper. Where about $12 \%$ respondents disagree about this statement.

Table 5. Well equipped class room.

\begin{tabular}{llllll}
\hline & & Frequency & Percent & Valid Percent & Cumulative Percent \\
\hline & Agree & 12 & 21.8 & 24.0 & 24.0 \\
Valid & strongly agree & 38 & 69.1 & 76.0 & 100.0 \\
& Total & 50 & 90.9 & & \\
Missing & System & 5 & 9.1 & & \\
Total & & 55 & 100.0 & \\
\hline
\end{tabular}

Source: Own survey, 2015 
Also, $76 \%$ respondents strongly agree and $24 \%$ respondents are agree with the statement of using well equipped class rooms in each university.

Table 6. Update course.

\begin{tabular}{llllll}
\hline & & Frequency & Percent & Valid Percent \\
\hline & Neutral & 6 & 10.9 & 12.0 & \\
Valid & Agree & 33 & 60.0 & 66.0 & 22.0 \\
& strongly agree & 11 & 20.0 & 100.0 \\
Missing & Total & 50 & 50.9 & 9.1 & \\
Total & System & 55 & 100.0 & \\
\hline
\end{tabular}

Source: Own survey, 2015

Non-government universities should update their courses regularly; majority of the respondents (66\%) agree with this statement.

Table 7. Rich online library.

\begin{tabular}{lllll}
\hline & & Frequency & Percent & Valid Percent \\
\hline Valid & strongly agree & 50 & 90.9 & 100.0 \\
Missing & System & 5 & 9.1 & 100.0 \\
Total & & 55 & 100.0 & \\
\hline
\end{tabular}

Source: Own survey, 2015

All of the respondents agree with the statement regarding introducing online library facilities in each university. So universities should use effectively online library.

Table 8. Motivation for research.

\begin{tabular}{llllll}
\hline & & Frequency & Percent & Valid Percent \\
\hline & disagree & 7 & 12.7 & 14.0 & Cumulative Percent \\
Valid & neutral & 14 & 25.5 & 28.0 & 14.0 \\
& agree & 29 & 52.7 & 58.0 & 100.0 \\
Missing & Total & 50 & 90.9 & & \\
Total & System & 5 & 9.1 & & \\
\hline
\end{tabular}

Source: Own survey, 2015

Faculty members and students should get motivation for research activities, more than $50 \%$ of the respondents agree with this.

Table 9. Online class participation.

\begin{tabular}{llllll}
\hline & & Frequency & Percent & Valid Percent & Cumulative Percent \\
\hline & Agree & 40 & 72.7 & 80.0 & 80.0 \\
Valid & strongly agree & 10 & 18.2 & 20.0 & 100.0 \\
& Total & 50 & 90.9 & 9.0 & \\
Missing & System & 5 & 100.0 & \\
Total & & 55 & & \\
\hline
\end{tabular}

Source: Own survey, 2015

There should be opportunities to attend the classes via online facilities, all of the respondents agree with this.

Table 10. Faculty exchange.

\begin{tabular}{lllll}
\hline & & Frequency & Percent & Valid Percent \\
\hline & neutral & 14 & 25.5 & 28.0 \\
Valid & agree & 36 & 65.5 & 72.0 \\
& Total & 50 & 90.9 & 100.0 \\
Missing & System & 5 & 9.1 & \\
Total & & 55 & 100.0 & \\
\hline
\end{tabular}

Source: Own survey, 2015

Majority of the respondents think that faculty exchange facility can improve the education quality. About $72 \%$ respondents 
agree and $28 \%$ gave their nutral opinion about this statement.

Table 11. Work load 4 teacher.

\begin{tabular}{llllll}
\hline & & Frequency & Percent & Valid Percent & Cumulative Percent \\
\hline & Disagree & 8 & 14.5 & 16.0 & 16.0 \\
Valid & Neutral & 8 & 14.5 & 16.0 & 32.0 \\
& Agree & 34 & 61.8 & 68.0 & 100.0 \\
& Total & 50 & 90.9 & 100.0 & \\
Missing & System & 5 & 9.1 & & \\
Total & & 55 & 100.0 & & \\
\hline
\end{tabular}

Source: Own survey, 2015

More than $50 \%$ of the respondents think excess work load of a teacher can reduce the quality of providing education where $60 \%$ are disagree about this statement.

Table 12. Credit transfer.

\begin{tabular}{llllll}
\hline & & Frequency & Percent & Valid Percent & Cumulative Percent \\
\hline & disagree & 8 & 14.5 & 16.0 & 16.0 \\
Valid & neutral & 23 & 41.8 & 46.0 & 62.0 \\
& agree & 19 & 34.5 & 38.0 & 100.0 \\
& Total & 50 & 90.9 & 100.0 & \\
Missing & System & 5 & 9.1 & & \\
Total & & 55 & 100.0 & & \\
\hline
\end{tabular}

Source: Own survey, 2015

When it comes to credit transfer systems improving the quality of education, $38 \%$ agree and $46 \%$ gave their neutral opinion with this statement.

Table 13. Latest learning.

\begin{tabular}{llllll}
\hline & & Frequency & Percent & Valid Percent & Cumulative Percent \\
\hline \multirow{3}{*}{ Valid } & agree & 14 & 25.5 & 28.0 & 28.0 \\
& strongly agree & 36 & 65.5 & 72.0 & 100.0 \\
Missing & Total & 50 & 90.9 & 100.0 & \\
Total & System & 5 & 9.1 & & \\
\hline
\end{tabular}

Source: Own survey, 2015

Universities should use latest learning materials. About $28 \%$ of the respondents are agree and $72 \%$ are strongly agree with this.

Table 14. Training for new teacher.

\begin{tabular}{llllll}
\hline & & Frequency & Percent & Valid Percent & Cumulative Percent \\
\hline & disagree & 8 & 14.5 & 16.0 & 16.0 \\
Valid & neutral & 8 & 14.5 & 16.0 & 32.0 \\
& agree & 34 & 61.8 & 68.0 & 100.0 \\
Missing & Total & 50 & 90.9 & 100.0 & \\
Total & System & 5 & 9.1 & & \\
\hline
\end{tabular}

Source: Own survey, 2015

More than $50 \%$ respondents agree that universities should provide training for new coming teachers where few $(16 \%)$ disagree with this statement.

\subsection{Qualitative Findings}

Based on the above information, the major findings are-

- Many non-government universities in Bangladesh don't have specific servers where faculty members can upload their regular classroom materials to which students would have an exclusive access with individual username and password.

- High speed internet facilities are not available in many private universities.

- In Bangladesh, many non-government universities do not offer a unique approach to online education. There are no flexible virtual classrooms where lectures can be presented instantly via software, voice commands, etc,

- Technologies such as video streaming, online testing and exam tools, wireless technologies, peer-to-peer 
collaboration, simulations and games, and assistive technologies are yet to emerge for online education in many Bangladeshi non-government universities.

- Often, students cannot access their learning resources from their homes. As many of the non-government university students are from well off families, they should maintain a laptop or tablet pc or handheld device which can be used to access the internet.

- Private universities need to enter into synergic engagements with all stakeholders in the society, keeping both national and international needs in mind. For this interuniversity collaboration is comparatively less. Collaborations can help the Bangladeshi students to get multicultural knowledge from other universities which in turn can improve the quality of education in the private sector level in Bangladesh.

- There are insufficient electronic journals or extensive collections in the libraries of many of the nongovernment universities. Access to the university's library through the internet from outside of the university is often not available. In this age of digitalization, it is not merely a luxury but rather a necessity.

- Students and their learning environment is not multinational. There is no facility in many of the campuses for students to live together so that global environment is maintained after classes, which is common in foreign private universities.

- Technical competency of newly appointed teachers should be improved so that they are able to provide online teaching.

- Syllabus and teaching materials in most university are not updated every year, resulting in certain inaction in teaching and research.

- Evaluation is an important part of ensuring the quality of education. Teaching efficiency rating is now available but isn't exercised effectively in all the nongovernment universities to evaluate the quality of education being provided by the faculty members in question.

- Various seminars, workshops and corporate presentation are not available except in some reputed nongovernment universities. Some universities arrange seminars but there is no scope to attend these seminars via the internet.

- The publication of quality research papers is unsatisfactory in non-government universities. Students and teachers from private universities are reluctant to publish research papers due to inefficient and insufficient facilities.

- Quite often, less meritorious students are admitted into non-government universities, sometimes without carrying out any admission test. It deters teachers from delivering lectures of the same quality for all types of students.

- Often non-government universities' students' do not exercise outside knowledge frequently. They are not expressive and cannot communicate well with others even after completing their graduation. Private universities need to address this matter.

- Sometimes, non-government universities have to compromise with the quality of the teacher due to their rapidly expanding nature. So the quality of the examination questions of all the teachers is not the same. These questions are not examined by examination committee in many of the non-government universities.

- Often qualified teachers are not motivated through different facilities or lack thereof in non-government universities.

- Poor supervisory and coordinating activities by the University Grant Commission (UGC). The failure of the commission in checking illegal practices by many private universities shows how vulnerable it has become to political and interest group pressure.

\subsection{Recommendations}

Based on the above findings, we would like to recommend some points to improve the quality of higher education in the non-government private universities in Bangladesh.

- Non-government universities should introduce wifi zone in each campus and provide high speed internet facilities.

- Facilities like google online drive can be made familiar where Instructors can make announcements, share course materials, and enhance discussion, all in one easily accessible location.

- Flexible virtual classrooms with audio/video and multimedia equipment for classes and presentationssuch as computer projectors and slide projectors for screened presentations, television monitors with VHS, DVD and blue ray capabilities for classroom screenings, and microphones for clearer and more audible lectures to enhance students' classroom multimedia experience with state-of-the-art equipment can be used.

- E-Portfolio sites can be introduced where collection of selected work in university's programs and courses are uploaded to make learning visible and help to publish samples of best research, projects, and university work that will impress the academic community and future employers.

- Learning management system can be introduced which will be used in on- and off-campus courses, certificate programs, and clerkships. Thus, students will be able to access course documents, send files to their instructor, and access grades directly when and where they like.

- There should be a practice that each student should keep a laptop or tablet computer or the latest hand held device with internet facilities just like a class diary in the class room.

- Online library facilities should be introduced and universities can arrange orientation program every semester for the new students to demonstrate how to use the internet resources in higher education and research, and how to design and maintain website, and set up 
online digital libraries.

- Inter-university partnership is important for synergic engagements. The collaboration of Bangladeshi nongovernment universities with Bangladeshi and foreign universities can be beneficial by sharing multicultural knowledge and experience, getting further scope for research activities and so on.

- The campus facilities and environment should be upgraded and be of the multinational kind so that international students can study and live together. Thus the demand for quality education will automatically increase.

- Course evaluation scanning services should be available to make adjustments and improvements in accordance with collected student feedback. Standard forms will provide a cost-effective means of capturing vital, accurate information.

- Newly appointed teachers should be offered some sort of training regarding technical competency such as online teaching.

- Syllabus and teaching materials should be upgraded regularly.

- Various seminars and workshops should be organized both at campus and at the virtual level. Such seminars can be conducted via video conferencing so that speakers form long distance can participate and this can improve the quality of non-government universities.

- Practical research activities and facilities like special allocation for publication should be introduced and exercised effectively for all students and teachers.

- Non-government education system should be supervised on regular basis through quality assurance arrangements including a national quality agency.

- Students can be classified according to their merit and less meritorious students should be provided extra care. There should be sufficient programs like taking viva after 2 or 3 semesters based on books as well as general outside knowledge to make them confident as well as expressive.

- There should be at least one examination committee to moderate the new teachers' questions and thus help them in their development..

- Non-government universities should offer better benefits regarding remuneration, incentives, residence facility and so on like public universities to motivate the qualified teachers.

\section{Conclusion}

Education in Bangladesh has come a long way since the bygone days of depending on only being lucky enough to be admitted into a reputed public university. The advent of nongovernment universities has injected hope for those eager students who wish to pursue higher education without having to leave Bangladesh, which in turn would cost them a lot of money. However, the progress made by non-government universities has been stalled for some time because of the commercial mentality of some of the private universities. Hopefully, this mentality and scenario is beginning to change and very soon, it is expected that non-government universities in Bangladesh will provide prospective students with the required qualifications that will help him/her towards a successful career. The goal of higher education is not only to create new knowledge and disseminate it, but also create skilled forces for the country to face development challenges. Quality and balanced education system can help to achieve this goal. There are fewer obligations for nongovernment universities to implement the above mentioned facilities because they do not have to deal with govt. politics, student politics and so on like a public university. If higher education delivery is diversified and made available online we might reach a substantial number of them. Higher education clearly needs a great deal of rethinking, redesigning and re adjusting. So if the above mentioned problems are resolved and the recommendations are to be implemented, non-government universities can soon overcome any negative publicity that many of them tend to receive and become a choice for future students. This in turn will help Bangladesh and its citizens as a whole towards achieving economic and technological development.

\section{References}

[1] Akareem, H. S. and Hossain, S. S., 2016. Determinants of education quality: what makes students' perception different?. Open Review of Educational Research, 3 (1), pp. 52-67.

[2] Andaleeb, S. S., 2003. Revitalizing higher education in Bangladesh: Insights from alumni and policy prescriptions. Higher Education Policy, 16 (4), pp. 487-504.

[3] Bhuiyan, M. N. U. and Hakim, M. A. (1995). Comparative cost of higher education in some selected countries: An analysis. Dhaka University Journal of Business Studies. 16 (1).

[4] Ehsan, M., 2009. Higher education governance in Bangladesh: the public private dilemma. VDM Publishing.

[5] Mamun, M. Z., Ahmed, N. and Faiz, S. B. S (2008), Customer focus of the private universities of Bangladesh: ATQM perspective, Journal Business administration, Vol. 34, No. $1 \& 2$, pp. 1-22.

[6] Sarkar, S. H., Rana, S. and Zitu, R. A., 2013. Challenges of quality higher education in Bangladesh: A study on public universities. Journal of Education and Practice, 4 (8), pp. 151161.

[7] Rony, M. E. and Rashid, S. M. A. (2009). Perspective of teaching-learning practices in private universities of Bangladesh. NAEM Journal, 5 (9), 67-77.

[8] Hoque, N., Mowla, M. M., Chowdhury, A. H., Uddin, M. S. and Chittagong, B., 2013. Quality of Education in Bangladesh: A Survey on Private Business Schools. dimensions, 3 (5).

[9] http://dspace.daffodilvarsity.edu.bd:8080/bitstream/handle/123 456789/668/CONSUMERS\%E2\%80\%99\%20PERCEPTION $\% 20 \mathrm{OF} \% 20 \mathrm{QUALITY} \% 20$ TOWARDS.pdf?sequence $=1$ 
[10] http://en.wikipedia.org/wiki/List_of_universities_in_Banglade sh\#Private universities

[11] http://futurestudents.yorku.ca/graduate/facilities_and_services

[12] http://heglobal.international.gbtesting.net/media/4289/quality $\% 20$ issues $\% 20$ of $\% 20$ higher $\% 20$ education $\% 20$ in $\% 20$ banglade sh.pdf

[13] http://jompesh.com/blogs/1/23915/private-universities-inbanglade

[14] http://mpra.ub.unimuenchen.de/10888/1/MPRA_paper_10888.pdf

[15] http://mytime.yorku.ca/whyyorku/

[16] http://web.usm.my/education/publication/jpp24_mohammadas hraf_17-32.pdf

[17] http://www.apu.ac.jp/rcaps/uploads/fckeditor/publications/jour nal/RJAPS_V22_Md_Tarafder.pdf

[18] http://www.assignmentpoint.com/business/organizational- behavior/success-factors-of-the-diffrent-public-and-privateuniversities-of-bangladesh.html

[19] http://www.bu.edu/online/

[20] http://www.eastwest.edu/facilities/

[21] http://www.educause.edu/ero/article/future-online-teachingand-learning-higher-education-survey-says

[22] http://www.educause.edu/ero/article/imagining-future-highereducation

[23] http://www.gla.ac.uk/studentlife/support/

[24] http://www.liberty.edu/online/

[25] http://www.startupdhaka.org/business/top-4-privateuniversities-in-dhaka-for-b-b-a/

[26] https://www.scribd.com/doc/21814815/Quality-of-HigherEducation-in-Public-and-Private-Universities-in-BangladeshSubmission\#scribd 